\title{
PENGARUH FDR, NPF DAN CAR TERHADAP PEMBIAYAAN MURABAHAH (Studi Kasus pada Bank Umum Syariah di Indonesia Periode 2015-2019)
}

\author{
Anisa Octaviani Noegraha \\ Universitas Singaperbangsa Karawang \\ (anisanoegrahaa@gmail.com)* \\ Nana Diana \\ Universitas Singaperbangsa Karawang \\ (nanadiana.ekonomi@gmail.com)
}

Disubmit: 6 Maret 2021

Mulai Review: 23 Maret 2021

Selesai Review: 28 April 2021

Diterima: 28 April 2021

\begin{abstract}
This study aims to see the effect of deposit financing (FDR) (X1) non-performing financing (NPF) (X2) Capital Adequacy Ratio (CAR) (X3) on murabahah financing (Y) in Islamic Commercial Banks for the period 2015-2019. The population in this study were all Sharia Commercial Banks recorded in the Financial Services Authority (OJK) for the 20152019 period. The sample of this study was 11 Islamic Commercial Banks from 14 total populations using quantitative methods with purposive sampling method. The analysis technique used in this research is descriptive statistical analysis, classic assumption test which includes normality test, multicollinearity test, heteroscedasticity test and autocorrelation test. Meanwhile, the data analysis used Multiple Regression, Determination Coefficient Test, Partial T Test, and Simultaneous F Test. The results of the T test showed that FDR and CAR partially had an effect on Murabahah Financing as long as the NPF variable had no significant effect on Murabahah Financing. Meanwhile, simultaneously there is a relationship between the variables FDR, NPF and CAR on Murabahah Financing together, these three variables have a significant effect on the variable murabahah financing.
\end{abstract}

Keywords: financing savings ratio, non-performing financing, capital adequacy ratio for Murabahah Financing

\begin{abstract}
Penelitian ini memiliki tujuan untuk mengetahui pengaruh financing deposit (FDR) ( $\left.\mathrm{X}_{1}\right)$ non performing financing $(\mathrm{NPF})\left(\mathrm{X}_{2}\right)$ capital adequacy ratio $(\mathrm{CAR})\left(\mathrm{X}_{3}\right)$ terhadap pembiayaan murabahah (Y) pada Bank Umum Syariah periode 2015-2019. Populasi dalam penelitian ini adalah seluruh Bank Umum Syariah yang terdaftar di Otoritas Jasa Keuangan (OJK) periode 20152019 Sampel penelitian ini berjumlah 11 Bank Umum Syariah dari 14 jumlah populasi dengan menggunakan metode kuantitatif dengan metode purposive sampling. Teknik analisis yang digunakan dalam peneitian ini menggunakan Analisis Statistik Deskriptif, Uji Asumsi Klasik yang meliputi Uji Normalitas, Uji Multikolinieritas, Uji Heteroskedastisitas, dan Uji Autokorelasi.
\end{abstract}


Sedangkan Analisis data menggunakan Regresi Berganda, Uji Koefisien Determinasi,Uji Parsial T, dan Uji Simultan F. Hasil penelitian Uji T menunjukan bahwa FDR dan CAR secara parsial berpengaruh terhadap Pembiayaan Murabahah sementara variabel NPF tidak berpengaruh signifikan terhadap Pembiayaan Murabahah. Sedangkan secara simultan terdapat hubungan antara variabel FDR, NPF dan CAR terhadap Pembiayaan Murabahah secara bersama-sama ketiga variabel tersebut memberikan pengaruh secara signifikan terhadap variabel pembiayaan murabahah.

Kata Kunci: financing deposit ratio, non performing financing, capital adequacy ratio Pembiayaan Murabahah

\section{PENDAHULUAN}

Saat ini, Perbankan syariah berdasarkan data yang diperoleh dari Otoritas Jasa Keuangan (OJK) per Bulan Desember 2019, Statistik perbankan syariah, jumlah industri Bank Umum Syariah (BUS) mencapai 14 Bank, Unit Usaha Syariah (UUS) sebanyak 20 Unit Usaha dan Bank Pembiayaan Rakyat Syariah (BPRS) sebanyak 164 Bank Pembiayaan Rakyat Syariah dengan total jaringan kantor sebanyak 2,300 kantor di seluruh Indonesia.

Dengan adanya bank syariah diharapkan dapat membantu perkembangan ekonomi negara. Fungsi perbankan syariah sebagai perekonomian negara ialah kemakmuran ekonomi, tingkat kerja dan pertumbuhan ekonomi yang optimal, keadilan sosial dan ekonomi serta pendapatan kekayaan yang merata, stabilitas nilai uang, mobilisasi dan investasi. Tujuannya yaitu untuk mengembangkan dan mempromosikan prinsip Islami ke dalam transaksi keuangan maupun bisnis lainnya.

Perbankan syariah merupakan pengembangan dari konsep ekonomi islam, yang bertugas untuk menghimpun dan menyalurkan dana untuk masyarakat yang berdasar pada prinsip syariat islam. Bank menghimpun dana masyarakat berbentuk simpanan. Tugas bank dalam menyalurkan dana ialah melalui pembiayaan. Pembiayaan atau Financing adalah pendanaan yang diberikan oleh suatu pihak lain untuk mendukung investasi yang telah direncanakan baik sendiri maupun kelompok.

Tabel 1. Pembiayaan Berdasarkan Jenis Akad Bank Umum Syariah 2015 - 2019 (dalam miliaran rupiah)

\begin{tabular}{lccccc}
\hline \multirow{2}{*}{ Jenis Akad } & \multicolumn{5}{c}{ Tahun } \\
\cline { 2 - 6 } & $\mathbf{2 0 1 5}$ & $\mathbf{2 0 1 6}$ & $\mathbf{2 0 1 7}$ & $\mathbf{2 0 1 8}$ & $\mathbf{2 0 1 9}$ \\
\hline Mudharabah & Rp. 168.516 & Rp. 156.256 & Rp. 151.719 & Rp. 146.247 & Rp. 240.606 \\
\hline Musyarakah & Rp. 652.316 & Rp. 774.949 & Rp. 739.562 & Rp. 737.620 & Rp. \\
& & & & & 1.121 .004 \\
\hline Murabahah & Rp. & Rp. & Rp. & Rp. & Rp. \\
& 4.491.697 & 5.053.764 & 5.097.883 & 6.204.187 & 7.457.774 \\
\hline Salam & Rp. 15 & Rp. 14 & Rp. 14 & 0 & 0 \\
\hline Istisna & Rp. 11.135 & Rp. 9.423 & Rp. 10.894 & Rp. 23.115 & Rp. 67.178 \\
\hline Ijarah & Rp. 6.175 & Rp. 6.763 & Rp. 7.302 & Rp. 24.204 & Rp. 41.508 \\
\hline Qardh & Rp. 123.588 & Rp. 145.865 & Rp. 154.506 & Rp. 168.200 & Rp. 176.856 \\
\hline Multijasa & Rp. 311.729 & Rp. 515.523 & Rp. 548.520 & Rp. 774.663 & Rp. 838.394 \\
\hline Total & Rp. & Rp. & Rp. & Rp. & Rp. \\
& 5.765.171 & 6.662.556 & 6.710.400 & 8.078 .236 & 9.943.320 \\
\hline Sumber: Stati
\end{tabular}

Sumber: Statistik Perbankan Syariah Desember 2019 
Pembiayaan murabahah mendominasi pembiayaan lainnya. Jumlah ini meningkat setiap tahun. Ini membuktikan bahwa pembiayaan Murabahah merupakan pembiayaan yang paling diminati masyarakat. Dibandingkan dengan jenis pembiayaan lainnya, (Adi, 2013)

Pembiayaan murabahah yang terbaik adalah karena lebih mudah penggunaannya, dan keunggulan pembiayaan murabahah adalah nasabah dapat memilih untuk membeli barang sesuai dengan keinginan dan kemampuan keuangannya, serta dapat pula mencicil, sehingga tidak membebani nasabah. Dalam alokasi dana (financing), besarnya pembiayaan Murabahah yang diberikan Bank Umum Syariah dipengaruhi oleh berbagai faktor, antara lain faktor internal dan eksternal. Faktor internal merupakan faktor yang dapat dikendalikan oleh perusahaan. Artinya kemampuan mengelola manajemen perusahaan merupakan kunci utama untuk mengendalikan faktor tersebut. Faktor internal financing deposit ratio (FDR), non performing financing (NPF), capital adequacy ratio (CAR). Selain faktor internal, pembiayaan Murabahah juga dipengaruhi oleh faktor eksternal. Jika faktor internal dapat sepenuhnya dikendalikan oleh perusahaan, maka faktor eksternal (seperti debitur, inflasi, dan makroekonomi) tidak dapat diprediksi atau dikendalikan. (Mizan, 2017)

\section{Bank Syariah}

Bank Syariah merupakan wujud institusi usaha yang mengimpun dana dari masyarakat dalam format simpanan dan kepada masyarakat dalam format kredit dan format lainnya dalam rangka meningkatkan tariff kehidupan masyarakat. No. 21 Tahun 2008 pasal 4, bank syariah dan unit usaha syariah wajib menjalankan fungsi menghimpun dan menyalurkan dana Undang-Undang Nomor 21 tahun 2008 tentang Bank Syariah dalam (Indonesia, 2008)

\section{Pembiayaan Murabahah}

Mudharabah merupakan transaksi penanaman dana dari pemilik dana terhadap pengelola dana untuk menjalankan aktifitas usaha tertentu yang layak untuk syari'ah, dengan pembagian hasil usaha antara kedua belah pihak menurut nisbah yang sudah disepakati sebelumnya (Muhamad, 2016)

\section{Financing Deposit Ratio (FDR)}

Rasio pembiayaan terhadap simpanan (FDR) adalah rasio antara jumlah pembiayaan yang diberikan Dana diterima oleh bank. FDR dapat dilihat dengan Rasio antara penyaluran dana yang disediakan oleh bank dan jumlahnya Dana publik atau dana pihak ketiga yang diterima, termasuk giro, Deposito dan tabungan. Rasio simpanan pembiayaan (FDR) adalah Tunjukkan kinerja bank dalam melunasi penarikan dana Deposan mengandalkan dana yang disediakan sebagai sumber likuiditas. Semakin banyak uang yang dikumpulkan bank, semakin banyak uang yang didapat Lihat kinerja bank dalam hal pembiayaan, dan sejauh mana kemampuan bank tersebut Kembalikan dana yang disimpan.

\section{Non Performing Financing (NPF)}

Berdasarkan rasio Non Performing Financing (NPL) Bank Indonesia yang membandingkan tingkat Non Performing Financing (NPL) (pembiayaan berkualitas) dengan total pembiayaan yang disediakan. Sedangkan menurut (Aziza, Sylvia, Mulazid, \& Sofyan, 2017). rasio masalah pembiayaan terhadap total pembiayaan yang dibayarkan oleh bank syariah. Berdasarkan standar 
yang ditetapkan oleh Bank Indonesia, kategori yang termasuk dalam Non Performing Financing (NPF) adalah kredit kurang lancar, mencurigakan dan bermasalah

Non Performing Financing (CAR)

Rasio kecukupan modal Itu adalah rasio itu Tunjukkan seberapa jauh Semua aset bank Berisi risiko (kredit, Investasi, sekuritas, Tagihan bank lain) Didanai dengan dana sendiri (Aziza et al., 2017). Semakin besar nilai mobil tersebut Kemampuan untuk berefleksi Bisnis perbankan semakin membaik Hadapi kemungkinan itu Resiko kerugian. Tangki mobil Diperoleh dengan membagi total Modal aset tertimbang Menurut risikonya (ATMR). Aset tertimbang Risiko (ATMR) adalah nilai total Aset bank masing-masing Setelah dikalikan dengan bobot risiko masing-masing asset.

\section{Hipotesis Penelitian}

$\mathrm{H}_{1}$ : Financing to Deposit Ratio (FDR) $\left(\mathrm{X}_{1}\right)$ berpengaruh positif terhadap Pembiayaan murabahah (Y)

$\mathrm{H}_{2}$ : Non Performing Financing (NPF) $\left(\mathrm{X}_{2}\right)$ berpengaruh negatif terhadap Pembiayaan Murabahah (Y).

$\mathrm{H}_{3}$ : Capital Adequacy Ratio (CAR) (X) berpengaruh positif terhadap Pembiayaan Murabahah (Y) $\mathrm{H}_{4}$ : Financing to Deposit Ratio (FDR), Non Performing Financing (NPF), dan Capital Adequacy Ratio (CAR) berpengaruh positif terhadap Pembiayaan Murabahah

\section{METODE PENELITIAN}

Jenis data yang digunakan dalam penelitian ini adalah data sekunder, dan metode penelitian menggunakan metode kuantitatif. Data diperoleh dari laporan tahunan Bank Umum Syariah..Populasi yang diambil dalam penelitian ini adalah 14 Bank Umum Syariah (BUS).laporan keuangan dari seluruh Bank Umum Syariah di Indonesia yang sudah terdaftar di Bank Indonesia period tahun 2015-2019. Kriteria Pengambilan sampel meliputi Bank Umum Syariah yang beroperasi dari 2015 - 2019 dan variabel - variabel yang diperlukan yaitu FDR, NPF dan CAR. Berdasarkan kriteria BUS yang memiliki kelengkapan data dan memenuhi syarat untuk dijadikan sampel sesuai dengan penelitian ini ada 11 BUS, yaitu BNI, Bank Victoria, BRI, BCA, Bank Bukopin, Bank Muamalat, Bank Aceh, Bank BTPN, Bank Panin dan Bank Mandiri, Bank Maybank. Untuk melengkapi uji asumsi klasik dan uji hipotesis dilakukan transformasi data dengan periode yang sama yaitu 5 tahun berturut-turut yaitu 2015, 2016, 2017, 2018 dan 2019.

Variabel Dependen dalam penelitan ini adalah Pembiayaan Murabahah (Y). Menurut (Kusnianingrum \& Riduwan, 2016), Pembiayaan murabahah adalah transaksi jual bleli dengan pembeli (Customer) dalam hal ini penjualan menyatakan harga asli, keuntungan tambahan di antaa kedua sisi.

Variabel independen dalam penelitian ini yaitu :

a. $\quad$ Financing to Deposit Ratio

Financing to Deposits Ratio (FDR) merupakan perbandingan jumlah pembiayaan yang disalurkan dari jumlah modal dana pihak ketiga yang berhasil dihimpun.

$b$. Non Performing Financing

Non Performing Financing (NPF) merupakan pembiayaan bermasalah dibandingkan total pembiayaan yang disalurkan

c. Capital Adequacy Ratio

Capital Adequacy Ratio (CAR) merupakan rasio kecukupan modal perusahaan yang menunjukkan kemampuan bank dalam mengantipasi sebuah resiko aktiva. 
Teknik analisis yang digunakan dalam peneitian ini menggunakan Analisis Statistik Deskriptif, Uji Asumsi Klasik yang meliputi Uji Normalitas, Uji Multikolinieritas, Uji Heteroskedastisitas, dan Uji Autokorelasi. Sedangkan Analisis data menggunakan Regresi Berganda, Uji Koefisien Determinasi,Uji Parsial T, dan Uji Simultan F.

\section{HASIL DAN PEMBAHASAN Anaisis Deskriptif}

Statistik deskriptif dalam penelitian ini memberikan gambaran atau deskripsi suatu data yang dilihat dari nilai rata-rata (mean), maksimum, minimum, median, modus dan standar deviasi. Berikut disajikan hasil olahan data SPSS untuk uji statistik dekriptif:

Tabel 2. Deskripsi Variabel Penelitian

\begin{tabular}{|l|r|r|r|r|r|}
\hline & \multicolumn{1}{|c|}{ N } & \multicolumn{1}{c|}{ Minimum } & \multicolumn{1}{c|}{ Maximum } & \multicolumn{1}{c|}{ Mean } & \multicolumn{1}{c|}{ Std. Deviation } \\
\hline FDR & 55 & 64,44 & 506600,00 & 17020,07 & 88325,14 \\
\hline NPF & 55 & 0,00 & 4,97 & 2,22 & 1,767 \\
\hline CAR & 55 & 11,51 & 241,84 & 29,24 & 36,66 \\
\hline Pembiayaan Murabahah & 55 & 4,00 & 40170,00 & 9407,31 & 10816,98 \\
\hline Valid N (listwise) & 55 & & & & \\
\hline
\end{tabular}

Sumber: Hasil Olah SPSS v.21

Berdasarkan hasil tabel 2. diatas diketahui bahwa Nilai N sebanyak 55, berdasarkan nilai rata-rata dari variabel FDR adalah $1.702 \%$ dengan nilai standar deviasi $8.832 \%$. Nilai maksimum dari FDR sebesar 5.066\% dan nilai minimum (terendah) sebesar 64\%. Nilai rata-rata dari variabel NPF adalah 2,22\% dengan nilai standar deviasi 1,767\%. Nilai maksimum dari FDR sebesar4,97\% dan nilai minimum $0,00 \%$ sebesar. Nilai rata-rata dari variabel CAR adalah $29,24 \%$ dengan nilai standar deviasi 36,66\%. Nilai maksimum dari CAR sebesar $241 \%$ dan nilai minimum (terendah) sebesar $11,51 \%$. Nilai rata-rata dari variabel Pembiayaan Murabahah adalah $9.407 \%$ dengan nilai standar deviasi $1.081 \%$. Nilai maksimum dari Pembiayaan Murabahah sebesar $4.017 \% \%$ dan nilai minimum (terendah) sebesar 4,00\%.

\section{Uji Asumsi Klasik}

\section{Uji Normalitas}

Tabel 3. Hasil Uji Normalitas

\begin{tabular}{|l|l|r|}
\hline \multicolumn{2}{|l|}{} & $\begin{array}{c}\text { Unstandardized } \\
\text { Residual }\end{array}$ \\
\hline N & Mean & 55 \\
\hline \multirow{2}{*}{ Normal Parameters ${ }^{\text {a,b }}$} & Std. Deviation & 9901,088755 \\
\hline \multirow{3}{*}{ Most Extreme Differences } & Absolute & 0,141 \\
\cline { 2 - 3 } & Positive & 0,126 \\
\cline { 2 - 3 } & Negative & $-0,141$ \\
\hline Kolmogorov-Smirnov Z & 1,045 \\
\hline Asymp. Sig. (2-tailed) & 0,225 \\
\hline
\end{tabular}

Berdasarkan tabel 3. diatas terlihat bahwa nilai signifikan sebesar 0,225. Nilai tersebut lebih besar dari $0,05(0,225>0,05)$, maka dapat disimpulkan bahwa data berdistribusi normal. 


\section{Uji Multikolinearitas}

Tabel 4. Hasil Uji Multikolineritas

\begin{tabular}{|c|c|c|c|c|c|c|c|c|}
\hline & \multirow[t]{2}{*}{ Model } & \multicolumn{2}{|c|}{$\begin{array}{c}\text { Unstandardized } \\
\text { Coefficients }\end{array}$} & \multirow{2}{*}{\begin{tabular}{|c|}
$\begin{array}{c}\text { Standard } \\
\text { ized }\end{array}$ \\
Beta \\
\end{tabular}} & \multirow[t]{2}{*}{$\mathbf{t}$} & \multirow[t]{2}{*}{ Sig. } & \multicolumn{2}{|c|}{$\begin{array}{c}\text { Collinearity } \\
\text { Statistics }\end{array}$} \\
\hline & & $\mathbf{B}$ & Std. Error & & & & Toleranc & VIF \\
\hline \multirow{4}{*}{1} & (Constant) & 19573,651 & 3911,794 & & 5,004 & 0,000 & & \\
\hline & FDR & 0,101 & 0,047 & 0,824 & 2,142 & 0,037 & 0,111 & 9,019 \\
\hline & NPF & $-1074,786$ & 840,295 & $-0,176$ & $-1,279$ & 0,207 & 0,872 & 1,146 \\
\hline & CAR & $-325,022$ & 116,177 & $-1,101$ & $-2,798$ & 0,007 & 0,106 & 9,435 \\
\hline
\end{tabular}

Sumber: Hasil Olah SPSS v.21

Berdasarkan tabel 4. uji multikolinearitas diatas dapat dilihat bahwa nillai VIF untuk FDR sebesar 9,019 lebih kecil dari 10. Nilai VIF dari NPF sebesar 1,146 lebih kecil dari 10 dan nilai VIF untuk CAR sebesar 9,435 lebih kecil dari 10. Maka dari itu dapat disimpulkan bahwa penelitian ini bebas dari gejala multikolinearitas.

\section{Uji Heteroskedastisitas}

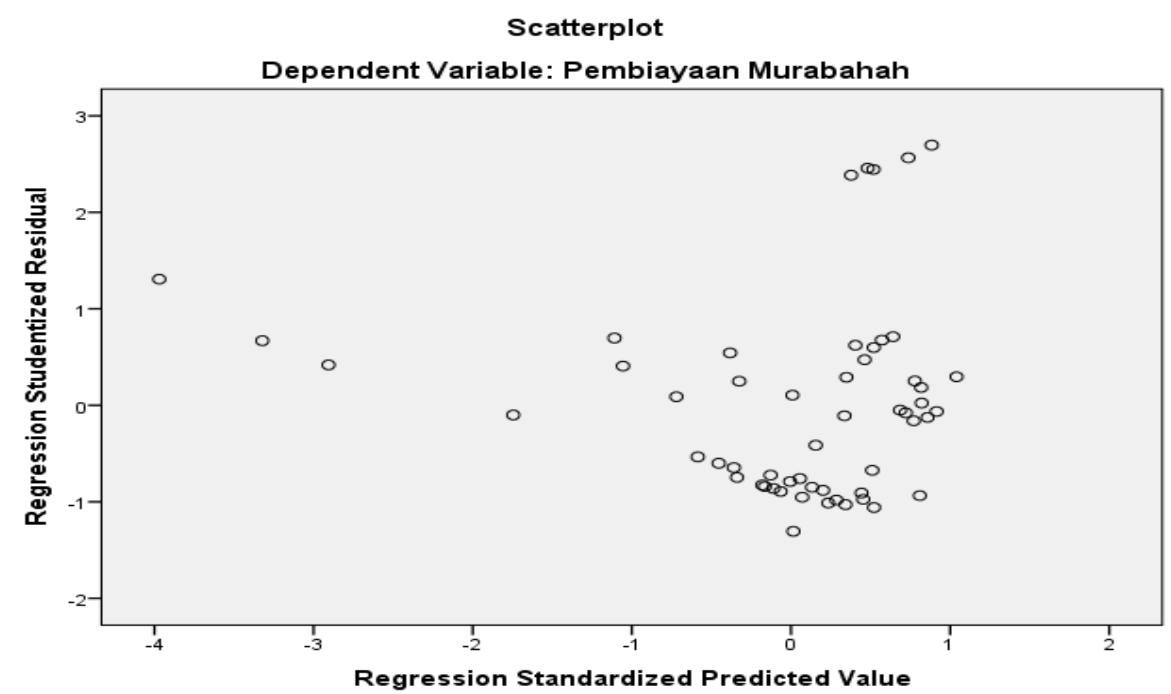

Gambar 1. Hasil Uji Heteroskedastisitas

Berdasarkan gambar 1. diatas dapat diperoleh gambar scatterplot dimana titik titik yang berada pada diatas dan dibawah angka 0 dan titik titik tersebut memiliki pola yang tidak beraturan. Maka dari itu dapat disimpulkan bahwa penelitian ini bebas dari heteroskedastisitas.

\section{Uji Autokorelasi}

Tabel 5. Hasil Uji Autokorelasi

\begin{tabular}{|c|r|r|r|r|r|}
\hline Model & \multicolumn{1}{|c|}{ R } & \multicolumn{1}{|c|}{ R Square } & \multicolumn{1}{|c|}{$\begin{array}{c}\text { Adjusted R } \\
\text { Square }\end{array}$} & $\begin{array}{c}\text { Std. Error of } \\
\text { the Estimate }\end{array}$ & $\begin{array}{c}\text { Durbin- } \\
\text { Wats on }\end{array}$ \\
\hline 1 &, $403^{\mathrm{a}}$ &, 162 &, 113 & 10188,14 &, 472 \\
\hline
\end{tabular}

Sumber: Hasil Olah SPSS v.21

Berdasarkan tabel 5. diatas menunjukan nilai Durbin-Watson sebesar 0,472 atau < 2 . Berdasarkan kriteria yang telah ditentukan DW hitung berada diantara -2 dan 2 yaitu $-2<0<2$. Jadi model regresi tidak terdapat autokorelasi. 


\section{Analisis Regresi linier berganda}

Tabel 6. Hasil Uji Regresi Linier Berganda

\begin{tabular}{|c|c|c|c|c|c|c|}
\hline & \multirow[t]{2}{*}{ Model } & \multicolumn{2}{|c|}{ Unstandardized Coefficients } & $\begin{array}{c}\text { Standardized } \\
\text { Coefficients }\end{array}$ & \multirow[t]{2}{*}{$\mathrm{t}$} & \multirow[t]{2}{*}{ Sig. } \\
\hline & & $\mathrm{B}$ & Std. Error & Beta & & \\
\hline \multirow{4}{*}{1} & (Constant) & 19573,651 & 3911,794 & & 5,004 &, 000 \\
\hline & FDR &, 101 &, 047 &, 824 & 2,142 & ,037 \\
\hline & $\mathrm{NPF}$ & $-1074,786$ & 840,295 &,- 176 & $-1,279$ & ,207 \\
\hline & CAR & $-325,022$ & 116,177 & $-1,101$ & $-2,798$ &, 007 \\
\hline
\end{tabular}

Sumber: Hasil Olah SPSS v.21

Berdasarkan tabel 6. diatas dapat diketahui bahwa nilai konstanta sebesar 19.573,651 lalu nilai koefisien FDR terhadap murabahah sebesar 0,101 sedangkan koefisien NPF terhadap murabahah sebesar -1.074,786 dan koefisien CAR terhadap murabahah sebesar -325,022. Dari hasil tersebut, maka dapat dibuat persamaan regresi sebagai berikut: $\mathrm{Y}=19.573,651+0,1 \mathrm{zzzz} 01 \mathrm{X} 1+(-1.074,786) \mathrm{X} 2+(-325,022) \mathrm{X} 3$

\section{Uji T (Uji Parsial)}

\section{Tabel 7. Hasil Uji T}

\begin{tabular}{|c|c|c|c|c|c|c|c|c|}
\hline \multirow{2}{*}{\multicolumn{2}{|c|}{ Model }} & \multicolumn{2}{|c|}{$\begin{array}{c}\text { Unstandardized } \\
\text { Coefficients }\end{array}$} & \multirow{2}{*}{$\begin{array}{c}\text { Standardized } \\
\text { Coefficients }\end{array}$} & \multirow[b]{2}{*}{$\mathrm{t}$} & \multirow[b]{2}{*}{ Sig. } & \multicolumn{2}{|c|}{ Collinearity Statistics } \\
\hline & & $\mathrm{B}$ & Std. Error & & & & Tolerance & VIF \\
\hline \multirow{4}{*}{1} & (Constant) & 19573,651 & 3911,794 & & 5,004 & ,000 & & \\
\hline & FDR &, 101 & 047 & ,824 & 2,142 & ,037 & ,111 & 9,019 \\
\hline & NPF & $-1074,786$ & 840,295 &,- 176 & $-1,279$ & ,207 & ,872 & 1,146 \\
\hline & $\overline{\mathrm{CAR}}$ & $-325,022$ & 116,177 & $-1,101$ & $-2,798$ & 007 & ,106 & 9,435 \\
\hline
\end{tabular}

Sumber: Hasil Olah SPSS v.21

1. Untuk variabel FDR menunjukkan nilai Thitung 2,142 lebih besar dari Ttabel 2,004. Atau, pada tabel nilai signifikansi 0,037 kurang dari 0,05 berarti $\mathrm{H}_{\mathrm{O}}$ ditolak $\mathrm{H}_{\mathrm{a}}$ diterima. Sehigga dapat disimpulkan bahwa secara parsial FDR berpengaruh signifikan terhadap pembiayaan murabahah.

2. Untuk variabel NPF menunjukkan nilai Thitung -1,279 (bernilai negatif) lebih kecil dari Ttabel - 2,004. Atau, pada tabel nilai signifikansi 0,207 lebih dari 0,05 berarti $\mathrm{H}_{\mathrm{O}}$ diterima $\mathrm{H}_{\mathrm{a}}$ ditolak. Sehigga dapat disimpulkan bahwa secara parsial NPF tidak berpengaruh signifikan terhadap pembiayaan murabahah.

3. Untuk variabel CAR menunjukkan bahwa nilai Thitung -2,798 (bernilai negatif) lebih besar dari Ttabel -2,004. Atau, pada tabel nilai signifikansi 0,007 kurang dari 0,05 berarti CAR berpengaruh signifikan terhadap pembiayaan murabahah. 
Noegraha \& Diana: Pengaruh FDR, NPF dan...

\section{Uji F ( Uji Simultan)}

Tabel 8. Hasil Uji F

\begin{tabular}{|c|l|r|r|r|r|r|}
\hline Model & \multicolumn{1}{c|}{ Sum of Squares } & \multicolumn{1}{c|}{ df } & Mean Square & \multicolumn{1}{c|}{ F } & Sig. \\
\hline \multirow{3}{*}{1} & Regression & 1024678398,811 & 3 & 341559466,270 & 3,291 &, $028^{\mathrm{b}}$ \\
\cline { 2 - 8 } & Residual & 5293704160,935 & 51 & 103798120,803 & & \\
\cline { 2 - 8 } & Total & 6318382559,745 & 54 & & & \\
\hline
\end{tabular}

Sumber: Hasil Olah SPSS v.21

Berdasarkan tabel 8. diatas, terlihat bahwa nilai Fhitung 3,291 lebih besar dari F tabel 3,179 serta nilai signifikansi sebesar 0,028 kurang dari 0,05. Hal ini berarti bahwa FDR, NPF, CAR secara bersama-sama (simultan) berpengaruh signifikan terhadap pembiayaan murabahah.

\section{Koefisien Determinasi}

Tabel 9. Hasil Uji Determinasi

\begin{tabular}{|c|r|r|r|r|r|}
\hline Model & R & R Square & $\begin{array}{c}\text { Adjusted R } \\
\text { Square }\end{array}$ & $\begin{array}{c}\text { Std. Error of the } \\
\text { Estimate }\end{array}$ & Durbin-Watson \\
\hline 1 &, $403^{\mathrm{a}}$ & 0,162 & 0,113 & 10188,13628 & 0,472 \\
\hline
\end{tabular}

Sumber: Olah SPSS v.21

Berdasarkan tabel 9. diatas dapat dilihat bahwa nilai koefisien determinasi atau Adjusted $\mathrm{R}$ Square adalah 0,113 atau 11,3\%. Hal ini berarti bahwa Murabahah dipengaruhi oleh ketiga variabel yaitu FDR, NPF dan CAR sebesar 11,3\% dan sisanya yaitu 88,7\% murabahah dipengaruhi oleh variabel lain yang belum diteliti pada penelitian ini.

\section{Pengaruh Financing Deposit Ratio (FDR) terhadap Pembiayaan Murabahah pada Bank Umum Syariah di Indonesia}

Dari hasil uji t-statistik hipotesis terlihat bahwa nilai signifikan dari FDR ditunjukan sebesar $0,037<0,05$. Oleh karena itu, hipotesis dalam penelitian ini menyatakan rasio FDR memiliki pengaruh yang signifikan terhadap pembiayaan murabahah. Oleh karena itu, semakin tinggi dana yang disalurkan bank dalam bentuk pembiayaan, maka semakin tinggi pula kemampuan bank dalam memberikan pinjaman. Dalam penelitian ini ditemukan bahwa FDR berpengaruh terhadap pembiayaan murabahab. Hasil penelitian ini konsisten dengan penelitian yang dilakukan (Kusnianingrum \& Riduwan, 2016) yang menyatakan bahwa fdr berpengaruh terhadap pembiayaan murabahah, dan bertentangan dengan penelitian (Rachmawaty \& Idayati, 2017) Yang menyatakan FDR tidak berpengaruh terhadap pembiayaan murabahah.

\section{Pengaruh Non Performing Financing (NPF) terhadap Pembiayaan Murabahah pada Bank Umum Syariah di Indonesia}

Dari hasil uji t-statistik hipotesis terlihat bahwa nilai signifikan dari NPF ditunjukan sebesar $0,207<0,05$. Oleh karena itu, hipotesis dalam penelitian ini menyatakan rasio NPF tidak berpengaruh signifikan terhadap pembiayaan murabahah. Dalam penelitian ini ditemukan bahwa NPF tidak berpengaruh terhadap pembiayaan murabahab. Hasil penelitian ini konsisten dengan penelitian yang dilakukan (Fahlevi, 2016) yang menyatakan bahwa NPF tidak berpengaruh terhadap pembiayaan murabahah, dan bertentangan dengan penelitian (Endang 2011) dalam (Purnomo \& Santoso, 2015). Yang menyatakan NPF berpengaruh terhadap pembiayaan murabahah. 
Jurnal Riset Akuntansi Aksioma Vol. 20, No. 1, Juni 2021

\section{Pengaruh Capital Adequacy Ratio (CAR) terhadap Pembiayaan Murabahah pada Bank Umum Syariah di Indonesia}

Dari hasil uji t-statistik hipotesis terlihat bahwa nilai signifikan dari CAR menunjukkan sebesar $0,007<0,05$. Oleh karena itu, hipotesis dalam penelitian ini menyatakan rasio CAR berpengaruh signifikan terhadap pembiayaan murabahah. Dalam penelitian ini ditemukan bahwa CAR berpengaruh terhadap pembiayaan murabahab. Hasil penelitian ini konsisten dengan penelitian yang dilakukan (Kusnianingrum \& Riduwan, 2016) yang menyatakan bahwa CAR berpengaruh terhadap pembiayaan murabahah, dan bertentangan dengan penelitian (Ali \& Miftahurrohman, 2016) Yang menyatakan CAR tidak berpengaruh terhadap pembiayaan murabahah pada bank umum syariah periode 2015-2019

Pengaruh Capital Adequacy Ratio (CAR), Non Performing Financing (NPF) dan Financing Deposit Ratio (FDR) Secara Simultan terhadap Pembiayaan Murabahah pada Bank Umum Syariah di Indonesia

Berdasarkan hasil penelitian, nilai signifikansi 0,028 lebih kecil dari 0,05. Artinya FDR, NPF dan CAR secara bersama-sama (simultan) mmiliki pengaruh signifikan terhadap pembiayaan murabahah pada bank umum syariah di Indonesia. Hal ini menyebabkan penerimaan Ha dan penolakan Ho.

Dengan demikian dapat disimpulkan bahwa FDR, NPF dan CAR secara simultan berpengaruh signifikan terhadap pembiayaan mrabahah. Hal ini didasarkan pada ketiga faktor saling mendukung dan terkait dengan pembiayaan murabahah. Hasil penelitian ini juga menunjukan bahwa hasil yang ditemukan peneliti sesuai dengan teori sebagai berikut, terdapat hubungan antara variabel FDR, NPF dan CAR secara bersama-sama ketiga variabel tersebut memberikan pengaruh secara signifikan terhadap variabel pembiayaan murabahah.

\section{SIMPULAN}

Berdasarkan hasil penelitian di atas, maka dapat ditarik kesimpulan. Pengaruh FDR (financing deposit ratio) terhadap pembiayaan murabahah memiliki pengaruh yang signifikan terhadap pembiayaan murabahah pada bank umum syariah di Indonesia. Pengaruh NPF (non perfoming financing) terhadap pembiayaan murabahah memiliki pengaruh yang signifikan terhadap pembiayaan murabahah pada bank umum syariah di Indonesia. pengaruh CAR (capital adaquacy ratio) terhadap pembiayaan murabahah memiliki pengaruh yang signifikan terhadap pembiayaan murabahah pada bank umum syariah di Indonesia. FDR, NPF dan CAR secara simultan berpengaruh signifikan terhadap pembiayaan murabahah pada bank umum syariah di Indonesia,

\section{DAFTAR PUSTAKA}

Adi, M. I. K. (2013). Faktor Faktor Yang Mempengaruhi Pendapatan Margin Pembiayaan Murabahah(Studi Kasus Pada Bri Syariah Dan Bank Mega Syariah). Skripsi.

Ali, H., \& Miftahurrohman, M. (2016). Determinan Yang Mempengaruhi Pembiayaan Murabahah Pada Perbankan Syariah Di Indonesia. Esensi: Jurnal Bisnis Dan Manajemen, 6(1), 31-44.

Aziza, Sylvia, R. V., Mulazid, \& Sofyan, A. (2017). Analisis Pengaruh Dana Pihak Ketiga, Non Performing Financing, Capital Adequacy Ratio, Modal Sendiri Dan Marjin Keuntungan Terhadap Pembiayaan Murabahah. Jebi (Jurnal Ekonomi Dan Bisnis Islam), 2(1), 1-15. 
Fahlevi, R. (2016). Analisis Pengaruh Inflasi, Sertifikat Bank Indonesia Syariah (Sbis), Non Performing Financing (Npf) Dan Dana Pihak Ketiga (Dpk) Terhadap Pembiayaan Murabahah Pada Bank Syariah Di Indonesia. Journal Article, 7(1), 71-82.

Indonesia, R. (2008). Undang-Undang No. 21 Tahun 2008 Tentang Bank Syariah. Jakarta: Sekretariat Kabinet Ri.

Kusnianingrum, D., \& Riduwan, A. (2016). Determinan Pembiayaan Murabahah (Studi Pada Bank Syariah Mandiri). Jurnal Ilmu Dan Riset Akuntansi, 5(1), 1-19.

Mizan, M. (2017). Pengaruh DPK, CAR, NPF, DER, Dan ROA Terhadap Pembiayaan Murabahah Pada Bank Umum Syariah. Balance: Economic, Business, Management And Accounting Journal, 14(01).

Muhamad. (2016). Manajemen Pembiayaan Bank Syari’ah. Yogyakarta: Upp Stim Ykpn.

Purnomo, H. W., \& Santoso, A. L. (2015). Analisis Faktor-Faktor Yang Mempengaruhi Pembiayaan Berbasis Margin Pada Bank Umum Syariah Di Indonesia. Sustainable Competitive Advantage (Sca), 5(1).

Rachmawaty, J. R., \& Idayati, F. (2017). Analisis Faktor-Faktor Yang Mempengaruhi Pembiayaan Jual-Beli Murabahah Pada Perbankan Syariah Di Indonesia. Jurnal Ilmu Dan Riset Akuntansi (Jira), 6(9). 